\title{
新刊書紹介
}

\section{The Shell}

\section{綺麗で希少な貝類コレクション 303}

真鶴町立遠藤貝類博物館著, 成山堂書店 (2015 年) $/ 20$ $\times 20 \mathrm{~cm}, 130$ 頁, 2700 円 + 税

海辺や湖畔に打ち上げられた貝殼にふと目がとまり, 造形の美しさに魅せられて持ち帰ったことのある読者も 多いだろう。貝殼は, 工芸品や装飾品の材料, 産業資材 や薬品の原料として, 古の時代から人間社会に活用さ れ，親しまれてきた。

本書は, 神奈川県真鶴町の初代教育長であり貝類研究 家として知られた遠藤晴雄氏（1915～2006）の名を取 って, 同町が 2010 年に開館した遠藤貝類博物館が保管 している 4 千 5 百種, 5 万点に及ぶ膨大な貝款のコレク ションの中から「宝石のような」303 点を厳選し，グラ ビア写真で紹介した書籍である。

本書の構成は次のと抢りである。第 1 章は「日本の 貝とオキナエビスガイ類」として, 生きている化石と呼 ばれる貝類として知られ，同博物館でメイン展示されて いるというオキナエビスガイ類を中心に 100 点余りの 貝類が紹介されている。第 2 章は「世界の貝」として, 「模様が派手な貝や非常に大きい貝など」90 点余りの貝 類が紹介されている。第 3 章は「真鶴の貝・相模湾の 貝」として，「アワビやサザエのような身近な貝類から 世界最小の貝「ミジンワダチガイ」など」 100 点余りの 貝類が紹介されている。各章の間には「人に利用された 貝」「貝の生活史」のコラムが挿入され，巻末には「貝 殼の不思議」「貝殼を脱いだ貝」「家に帰る貝」「生きて いる化石と呼ばれる貝」の随筆が添えられ, 最終ページ には, 同博物館の概要と執筆者の紹介がさりげなく収録 されている。

本書に収録された貝殼の写真は, 縮尺にこだわらず, 黒地や紺地の紙面に様々な向きで配置され, 形状や色の 多様さが強調されている。写真の傍らには, 生息地, 外 見の特徵, 殼長や殼幅などの解説が添えられ, 特に目を 惹くのは,「翁恵比寿貝」のように漢字名が併記されて いることである。詳細な目次と索引により, 貝の名称か ら写真を見つけ出すことも可能である。

通信機器や記憶媒体の発達により, 動画付きの百科事 典が外出先からも参照できる時代である。しかし, 本書 を手に取った読者は, 貝類の種類の多さや貝殼の形状や 色の多様さを改めて認識し，その美しさを自らの目で見 たくなるであろう。そのことを可能にしているのは, 種 類が膨大で, 産地や成長度によっても形状や色が異なる サンプルの中から, 美術的であり学術的な価值を見出せ る標本を選抜し, 展示場所を確保し, 適切な解説を添 え, 伝統工芸品にも匹敵する厳しい管理の下で，公開を 続ける貝類博物館の情熱や努力のおかげであることも, 同時に気づかされるに違いない。

（農林水産政策研究所 高橋祐一郎）

\section{水産総合研究センター叢書 \\ Impact of the Fukushima Nuclear Acci- dent on Fish and Fishing Grounds}

中田 薰 - 杉崎宏哉 編, Springer open (2015 年) $/ 160$ $\times 240,238$ 頁 $\$ 59.99$

2011 年 3 月に発生した東京電力福島第一原子力発電 所の事故により, 周辺の海域抢よび陸水域が大量の放射 性物質, 特に放射性セシウムにより污染された。福島県 を中心に, 周辺地域の水産業は甚大な被害を受け, 震災 から 5 年以上が経過した現在においても, 一部の魚 種・地域で出荷制限の措置が継続するなど, 原発事故の 影響が続いている。「原発周辺に生息する水産物はどの ように污染され, 今後, それらの放射性物質濃度はどの ように低下していくのか?」「水産物の放射性物質污染 メカニズムはどの程度明らかにされているのか?」本書 には, 研究者や消費者が抱くであろう, これらの問いに 対する多くの答えが示されている。

本書は, 水産総合研究センターの研究者らが, 原発事 故直後から 3 か年にわたり精力的に行った放射性物質 調査の成果の結集である。調査対象は, 海水魚や淡水魚 などの水産物にとどまらず，プランクトン， ベントス， 抢よびそれらの生息環境（海水・陸水・底土等）々多岐 にわたる。これらの膨大なデータを, 統計解析や数值シ ミュレーションも交えながら多面的に分析し, 水産物の 放射性物質污染プロセスに科学的根拠を与えている点が 本書の最も大きな特徵である。また, 環境モニタリング 調査に加えて, 多様な調査手法を用いて対象生物の污染 メカニズムの解明に迫る点も本書の特徵である。例え ば, 高濃度に污染されたアイナメの耳石中のベータ線の 定量分析や, 飼育試験による多毛類の底土からの污染状 沉の把握, ケージ試験を用いたヒメマスの污染経路の特 定など, 水産研究者ならではの知識と知恵を活かした調 查やデータ分析が随所に認められる。

本書は, 序章を含め 19 編の論文で構成されている。 各論文は, 要約と背景に続いて課題ごとの説明が示され ており，一般的な学術誌に比べて読みやすい構成となっ ている。執筆者らが震災以前より担当する対象を扱って いる課題も多く, 水産学や海洋学に支えられた解釈は読 みごたえ十分である。これだけ充実した内容がオープン アクセスであることもありがたい限りである。水産研究 者はもちろんのこと, 学生の皆さんもぜひダウンロード して一読することを扸めしたい良書である。

（福島大 和田敏裕） 


\section{新刊書紹介}

\section{乱獲 漁業資源の今とこれから}

Ray Hilborn - Ulrike Hilborn 著, 市野川桃子 - 岡村寛 訳, 東海大学出版部 (2015 年) / A 5 判, 154 頁, 2,900 円十税

「乱獲」は，マスメディアを通じて一般の人にもよく 知られた言葉である。しかし，「乱獲」の何が問題なの か，何ができるのか，について理解している人は多くな いだろう。本書は, 漁業に抢ける様々な「乱獲」や「乱 獲」に関連する話題を幅広い読者に提供し，持続的な漁 業資源利用の一助となるよう執筆された原著の翻訳本で ある。本書は, 原著者が ‘日本語版にむけて’の中で, 「乱獲」が適切な管理によって解決しうる問題であるこ とを知ってもらいたい，と述べているように，「乱獲」 の基礎から「乱獲」に対応するための管理方法に関する 話題が幅広くかつ実例を挙げながら紹介されている。

本書は節タイトルで疑問文を使い質問を投げかけ，本 文で回答する構成になっており，節タイトルに関連する 定義や状況が詳しく紹介されているので問題点と現状が わかりやすい。第 1 から 5 章は, 「乱獲」の定義から始 まり，「乱獲」のこれまでの歴史や状況の説明がなされ て抢り，「乱獲」に関する背景が理解できるようになっ ている。次に, 第 6,7 章では漁業の背景となる気候変 動, 生態系との関連について取り上げ漁業が自然の恵み を利用していることを再確認している。その後に, 第 8 から 13 章の具体的な漁業（異なる漁場での漁業や異な る漁法を用いた漁業）の状況の紹介に移る。第 14 章で は漁業資源を含む海洋資源の保護方策として海洋保護区 が紹介され問題点が示され, 最後に, 漁業資源が生態系 に与える影響抢よび世界の「乱獲」の現状を紹介されて いる(第 15,16 章)。

訳者あとがきで, “「どのように漁業資源を管理すれば 解決できるのか?」「どのようなことが解決への妨げに なっているのか?」を多くの人が知り，考えてもらいた かった”という言葉の通り, 平易な文章で記述されてお り，原著書にない写真や図により理解が進むに違いな い。また,「乱獲」問題に対する原著者の考元, 現状々 理想の間の葛藤を垣間見ることができる。本書の出版記 念として, 平成 28 年度日本水産学会春季大会中に開催 されたミニシンポジウム「漁業資源の今とこれから」の 報告記事が日本水産学会誌に揭載されるので本書ととも に併せて読んで頂きたい。（海洋大 岩田繁英）

\section{水産総合研究センター叢書 \\ 生物資源解析のエッセンス}

赤嶺達郎 著, 恒星社厚生閣(2016 年)/B4 判, 125 頁,

2,500 円十税

本書はまずこんな問題から話が始まる。「3つの扉が あり，その 1 つの扉の裏に自動車が置いてある。その 屝を当てると自動車がもらえる。解答者が 1 つの扉を 指定すると, 正解を知っている司会者は残り 2 つ屝 のうち, (自動車のない) 1 つを開く。その後解答者は 1 回だけ扉を変更できるが, 変更した方が有利か? そ れとも無意味か? 」変更した方がよさそうでもあり, 変 わりなさそうでもある。考えているとわけが分からなく なるが，数学者も含めて多くの人がこの問題には惑わさ れているようなので心配いらない。本書ではべイズ定理 を用いてこれを明快に説明する。こういった問題を考え るのを楽しめるのか，それとも面倒と思うのかで好みは 分かれるであろう。

本書は 2007 年の「水産資源解析の基礎」, 2010 年の 「水産資源のデータ解析入門」に続く著者の第 3 作目と なる。2 作目と同様に, A 先生と $\mathrm{S}$ 君の会話調で話は進 む。取つきやすいが，それなりにじっくりと読む必要が ある。内容はべイズ統計, ランダムウオーク, 微積分, 線型代数, 確率分布等多岐に渡る。一部を除きこれらの 入門書というより，多少なりとも知識のある人が頭を整 理するかより理解を深めるためのものであらう。前 2 著では水産資源学に関連する話が中心となっているが, 本書ではもっと一般的な立場から書かれて抢り, より広 い読者を対象としている。最近では水産分野でも様々な 数理・統計手法が使われているが, 表面的な理解の下や ブラックボックス的に使われている場合もあると思われ る。しかし，自分の頭で考えだすと分からなくなること も多い。本書の中に対応する話題があれば，そのような 時には役立つであろう。また後半では数理統計に関連す る様々な話題が触れられている。例えば最後に出てくる 「漁獲尾数などのデータで最初の数字は 1 や 2 のような 小さな数字が多い」(ポアンカレのルーレット定理）と いった話は初めて知ったが, 斜め読みでもこういった興 味深い知識を得ることができる。

いずれにせよ，根本に立ち戻り基本的な所からじっく り考えることの重要性を再認識させられる書である。 （東大大気海洋研 平松一彦） 